\section{Microdetection of Nitrite with Malachite Green or Congo Red}

Mikronachweis von Nitrit mit Malachitgrün oder Kongorot

Nachw. von Nitrit mit Malachitgrün oder Kongorot

\section{G. S. Johar and G. D. Tiwari}

Dept. of Chemistry, V. S. Sanatan Dharma College, Kanpur-208002, India

Received September 9, 1972; revised November 18, 1972

The following procedures are proposed for a rapid and sensitive detection of nitrite :

\section{Malachite Green as Reagent}

Take $0.25 \mathrm{ml}$ of neutral sample solution in a micro test-tube, add 2 drops of $0.1 \%$ aqueous Malachite Green solution, and acidify the mixture with 1 or 2 drops of dilute hydrochloric acid $(20 \mathrm{ml}$ conc. acid diluted with $60 \mathrm{ml}$ water $)$. A positive response is indicated by the appearance of a deep red or deep reddish-purple colouration. The brightness of the colour increases in a few seconds, but on keeping further, however, it loses its brightness and intensity gradually, becoming light red-purple after several sec., and disappears ultimately (in 1 to $3 \mathrm{~min}$ ) giving a colourless solution. In the absence of

\section{Direct EDTA Titration of Copper(II) and Iron(III)}

Direkte Titration von Kupfer(II) und Eisen(III) mit ÄDTA

Best. von Kupfer(II) mit Eriochromoyanin R; Volumetrie; ÅDTA.

Best. von Eisen(III) mit Gallocyanin;

Volumetrie; ÄDTA.

Rajinder Pal Singh

Department of Chemistry, Panjabi University, Patiala, India

Received August 28, 1972; revised November 28, 1972

It has been found that copper(II) and iron(III) can be suitably titrated by EDTA using Friochrome Cyanine $\mathbf{R}$ and Gallocyanine, respectively, as indicator.

\section{Copper(II)}

One advantage of the procedure described is the fact, that the colour change becomes increasingly contrasting towards the end-point, clearly showing the progress of the titration. $0.2-40 \mathrm{mg}$ of $\mathrm{Cu}$ were determined with good accuracy. Alkaline earths in moderate amounts do not interfere. nitrite the colour of the dye solution is pale yellowish-green or yellow.

Limit of detection : $75 \mu \mathrm{g} \mathrm{NO}-10.25 \mathrm{ml}$.

\section{Congo Red as Reagent}

Take $0.5 \mathrm{ml}$ of neutral test solution in a micro test-tube, add 2 drops of $0.1 \%$ aqueous Congo Red solution, and acidify the mixture with 1 drop of dilute hydrochloric acid (conc, acid : water, $1: 1$ ). Then add 2 or 3 drops (avoid excess) of acetone, close the mouth of the tube with a thumb, and shake thoroughly for a few sec. Appearance of a violet or purple colour (or precipitate) indicates the presence of nitrite. A blank test gives deep blue colour or precipitate, obtained invariably on acidifying Congo Red solution. Addition of acetone helps in. crease the brightness of the purple colouration caused by nitrite.

Limit of detection: $550 \mu \mathrm{g} \mathrm{NO}-10.5 \mathrm{ml}$.

Common anions and cations do not interfere in the tests. The only interference is caused by iodide and by azide in large amounts.

This work was supported financially by the University Grants Commission (U.G.C.), New Delhi.

Dr. G. S. Johar

Department of Chemistry

V.S. Sanatan Dharma College

Kanpur-208002, India
To the sample solution with not more than $30 \mathrm{mg}$ of $\mathrm{Cu}$ $100 \mathrm{ml}$ add $0.4-0.5 \mathrm{ml}$ of $0.2 \%$ aqueous Erichrome Cyanine $R$ solution for each $15 \mathrm{mg}$ of $\mathrm{Cu}$, adjust the $\mathrm{pH}$ to 5.8-6.2 with solid hexamine and titrate with $0.01 \mathrm{M}$ or $0.05 \mathrm{M}$ EDTA solution to a yellow green colour having passed through blue, red and pink. In weaker solutions adjust the $\mathrm{pH}$ to $6-6.2$. Prepare the indicator freshly for microdeterminations.

\section{$\operatorname{Iron}(I I I)$}

An extremely sharp end-point is received in this titration from violet-red to blue, also in the reverse titration. Whereas moderate amounts of $\mathrm{Mn}$ do not interfere in the direct procedure, the indirect one is blocked. Cr can be better tolerated in the indirect titration. Alkaline earths do not interfere.

Add to the acidic sample solution containing $1-50 \mathrm{mg}$ of iron(III) a major portion of $0.05 \mathrm{M}$ or $0.01 \mathrm{MI}$ EDTA solution, $0.5-1 \mathrm{ml}$ of $0.05 \%$ indicator solution (see below) and dilute to $50-100 \mathrm{ml}$. Add dropwise $1 \mathrm{M}$ sodium acetate or sodium acetate buffer $\mathrm{pH} 5$ till the pink colour $(\mathrm{pH}<3$ ) changes from. violet $(\mathrm{pH} \mathrm{3-4)}$ ) to violet red ( $\mathrm{pH} 4.2-5)$. Continue the addition of EDTA to a sharp colour change from violet red to blue. A reverse titration is also possible. Addition of the indicator near the end-point is essential for a sharp colour change.

Dr. R. P. Singh

Department of Chemistry

Panjabi University

Patiala, India 